\title{
The Determinants of Indonesian Textile's and Clothing Export to the Five Countries of Export Destination
}

\author{
Faizal Irvansyah ${ }^{1 *}$, Hermanto Siregar ${ }^{2}$, Tanti Novianti ${ }^{3}$ \\ *Corresponding author
}

\begin{abstract}
Indonesian textile and clothing products (TPT) is the second-largest export product after oil palm product. There are five biggest export destination countries, that is the United States, Japan, South Korea, and Turkey. This study aims to analyze the factors that affect TPT exports to the five biggest export destination countries. The factors that affect TPT exports examined by using time series and panel data analysis. Using panel data analysis finds that GDP per capita of the destination country, the exchange rate of the Rupiah, the price of textiles in the destination country, and import tariffs stipulate in the destination country affect TPT exports. Then, using time series analysis finds that GDP per capita and import tariffs affected TPT export to the United States, China, and Turkey. Meanwhile, the factors influencing Indonesian textile exports to Japan and South Korea are textile prices, rupiah exchange rates, and import tariffs.
\end{abstract}

Keywords: textile and clothing product, the competitiveness of textile and clothing, export

JEL Classification: F14, F43

\begin{abstract}
Abstrak. Tekstil dan Produk Tekstil (TPT) merupakan produk ekspor terbesar kedua setelah produk kelapa sawit. Produk TPT Indonesia sebagian besar di ekspor ke lima negara tujuan ekspor, diantaranya adalah Amerika Serikat, Jepang, Korea Selatan, China, dan Turki. Penelitian ini akan menganilisis faktor yang mempengarubi ekspor TPT Indonesia di lima negara tujuan ekspor tersebut. Penelitian ini menemukan bahwa GDP per kapita di negara tujuan, nilai tukar rupiah, harga produk TPT, dan tarif impor mempengarubi ekspor TPT Indonesia. Kemudian faktor yang mempengaruhi ekspor TPT untuk ke negara Amerika Serikat, China, dan Turki adalah GDP per kapita dan tarif impor. Sedangkan, untuk negara Jepang dan Korea Selatan adalah harga TPT, nilai tukar rupiah, dan tarif impor.
\end{abstract}

Kata Kunci: tekstil dan produk tekstil, daya saing tekstil dan produk tekstil, ekspor

\section{How to Cite:}

Irvansyah, F., Siregar, H., \& Novianti, T. (2020). The Determinants of Indonesian Textile's and Clothing Export to the Five Countries of Export Destination. Etikonomi: Jurnal Ekonomi, 19(1), 19 - 30. https://doi.org/10.15408/etk. v19i1.14845. 


\section{Introduction}

The era of liberalization and globalization of the world economy today has brought fundamental changes to cross-border trade and economic patterns. Trade partners between countries not just only bilateral and regional only, but also expand to be multilateral and international. Economic globalization illustrates there is a freedom for all economics agents to determine themselves what they will consume, what they will produce, how to produce it. Therefore, all industries are required to have competitiveness to survive in high competition. Until now, the Indonesian government continues to increase competitiveness in the sector that is important for the Indonesian economy. This manufacturing industry sector plays a role in increasing Indonesia's gross domestic product (GDP) and exports. Besides that, Indonesia's manufacturing sector is mostly a labor-intensive industry that will absorb many human resources.

One of the manufacturing industries prioritized by the Indonesian government is the textile and clothing (TPT) industry. The TPT industry is one of the priority industries developed in the long term. Based on Government Regulation No. 14 of 2015 explains that the TPT industry is a priority industry because it meets various criteria, including meeting domestic needs and import substitution, increasing the quantity and quality of employment, having an added value that is growing progressively domestically, have good competitiveness. Textile generally can be interpreted as goods or things that come from fibers (cotton, polyester, and rayon) that as spun into yarn or woven or knitted become clothes. The cloth can be processed into various products such as garments and so on. Textile industry consists of 3 sectors, namely the upstream industry sector, medium industry sector, and downstream industry sector (Chamroel, 2003). The upstream industry sector is an industrial sector that produces cloth (natural fibers, synthetic fibers, and rayon fibers).

In the upstream industry sector, usually capital-intensive and technology-intensive. Then in the medium industrial sector is an industry that makes the processed yarn into raw sheet cloth with weaving, knitting, and finishing. This sector has the characteristics of semicapital intensive (more human resources than the upstream sector) and the use of medium and modern technology. Finally, the downstream industry sector is a garment manufacturing industry. This industrial sector is usually labor-intensive.

The textile exports mostly sent to five destination countries. The five destination countries are the United States, Japan, and the People's Republic of China, South Korea, and Turkey. Based on the data from the Indonesian Ministry of Trade that the value of the textile to the five countries in 2017 in the amount of $30.9 \%$ of Indonesia's total textile exports. Meanwhile, $69.1 \%$ of textile exports spread throughout the world. Among the five countries, the United States is the largest export destination country. The value of textile exports to the United States is in the amount of 58.8\% of the total export value of the five largest export destination countries.

The TPT industry is the second largest contributor to exports after oil palm, the industry that has a role in non-oil exports in the amount of $8.2 \%$, while oil palm has a role in non-oil exports in the amount of $12.32 \%$. Although The TPT industry is the second-largest export 
commodity, the trend from 2012-2016 has decreased. The trend of export value in the textile from $2012-2016$ is $-1.35 \%$. The decline in the TPT export trend illustrates the decline in the competitiveness of TPT. Similar research has also carried out in several countries. Baskol (2018) found that the level of competitiveness of the apparel sector in Turkey was better than the textile sector from 1985-2007. However, there is one product that has a decreased level of competitiveness, namely SITC 846 (clothing accessories from textile fabrics). Furthermore, since 2008-2015 the textile sector has a higher level of competitiveness compared to the apparel sector.

Every country is trying to increase TPT exports, and one of them is China. China's textile export growth is very rapid. The rapid growth of Chinese textile exports threatens Egyptian textiles for the United States and European Union markets. The study also found that Egyptian textile exports declined in both markets (Hatab, 2017). Zyl \& Matswalela (2016) found that the level of competitiveness of the TPT industry in South Africa is the lowest compared to 18 other developing countries. Then using the analysis of the fixed effect panel data found that rising labor costs and declining export market share as the primary determinant of the level of competitiveness of the TPT industry in South Africa.

Latif \& Javid (2016) analyzed the demand and supply factors of Pakistan's textile products to the seven export destination countries. This study found that income in export destination countries and the easing of policies greatly affected exports. Wahyuni \& Boeditomo (2015) analyzed labor factors that could affect the competitiveness of the Indonesian textile industry compared to Vietnam. This research shows that several factors improve in terms of the labor force in Indonesia. These factors include occupational safety and health, training, working time, timely payment, and life satisfaction.

Although based on data released by BPS that the TPT export trend is declining, but based on research conducted by Kuncoro (2013) states that the level of TPT consumption will increase along with the increasing world population. Indonesia's TPT export level predicts to increase by $12.6 \%$ annually. Hendria (2017) found that the apparel industry has a competitive advantage compared to other countries for export destinations. Then, the factors that significantly affect the flow of trade are real GDP per capita of export destination countries, the exchange rate of Rupiah, and the export price of apparel products, FTA, and previous export. Kusuma \& Firdaus (2015) found that the factors which influence export volume, namely economic distance, Gross Domestic Product (GDP), exchange rate, population, and price of the product. Then, Kathuria (2013) found that the factors which influence the textile industry in India, namely human resources wage, electric costs, transaction costs, and human resources productivity.

Based on the several factors found from several kinds of research, some factors often arise in influencing exports, which is the gross domestic product (GDP) per capita and exchange rates. Gross domestic product (GDP) per capita chose because it can describe the average standard of living and economic welfare in a country. Gross domestic product (GDP) per capita is the value of goods or services in a particular year divided by the population. Then, the exchange rate is the price rate of the domestic currency against foreign currencies. 
The change in the exchange rates can change the relative price of a product to become more expensive or cheaper.

Furthermore, several factors also influence exports, namely the product prices and import tariffs. The price of a product is the value of an item. The measurement is using the value of the money that spent to get goods or services. The price of a product can influence the offer. Finally, the import tariffs are a charge that imposed on an imported good that enters into a country. Generally, this import tariffs is one of the obstacles in international trade.

Referring to Hendria (2017), the research only analyzes two types of textile products for several export destination countries. The most significant TPT product exports export to the United States, Japan, China, South Korea, and Turkey. According to Kuncoro (2013) that Indonesia's TPT exports predict to increase along with an increase in the world population. In general, the increase in exports was not only influenced by an increase in the world population. Several other factors can increase exports. Based on both studies, this research will analyze all TPT products listed in the two digits HS Code (HS Code 50 - HS Code 62) and will carry out for the five largest export destination countries. HS (Harmonized System) is a codification for goods coordinated by The World Customs Organization (WCO) (Harjanto \& Purwanto, 2010).

The previous studies analyzed two types of Indonesia TPT Products, and the factors that can predict Indonesia TPT export is an increase in the world population. This study analyzes all of the TPT products listed in the two digits HS Code. Several factors can predict Indonesia's TPT export to increase Indonesia's TPT Export, such as GDP per capita in the export destination country, the exchange rate of Rupiah against the export destination country, the price of textile, and the import tariffs that imposed in the export destination countries.

Therefore, this study aims to know the determinants of TPT exports, especially to the five export destination countries. This condition is because; the Indonesian TPT industry is the most easily influenced by market dynamics (Asmara et al., 2016). The influencing factors will be analyzed based on TPT products that have competitiveness based on RCA analysis. This research will contribute to determining strategies to increase Indonesia's TPT export.

\section{Methods}

The data used in this research are the annual data from 2001 to 2017. The data used from five top destination countries of TPT (USA, Japan, China, South Korea, and Turkey). The data is only used until 2017 because at the time this study was compiled, the data in 2018 was still temporary. If using the 2018 data, the results of this study cannot clearly show the influencing factors. To achieve the objectives of this study, the data used were from 2001-2017. This research uses time series analysis and panel data analysis with variable rupiah exchange rates, textile product prices, import duties, and GDP per capita. The research model that used to estimate the main factors is as follows:

$$
\text { Export }_{\mathrm{it}}=\alpha_{0}+\sum \beta_{1} \text { Exchange Rate }_{\mathrm{it}}+\sum \beta_{2} \text { Price }_{\mathrm{it}}+\sum \beta_{3} \text { dTarif }_{\mathrm{it}}+\sum \beta_{4} \mathrm{GDP}_{\mathrm{it}}+\varepsilon_{\mathrm{it}}
$$


Export $_{i \mathrm{i}}$ is the magnitude of the real value of Indonesia's textile exports to "i" countries and " $\mathrm{t}$ " times. The value of Indonesian textile exports to the export destination countries uses export values based on HS code two digits code. The textile product among other silk, Wool, Cotton, Other Vegetable Textile Fibers, Man-Made Filaments, Man-Made Staples Fibers, Wadding, Carpets, Special Woven Fabrics, Laminated Textile Fabrics, and Crocheted Fabrics, apparel and clothing accessories, knitted or geared crocheted, and apparel and clothing accessories, not knitted or crocheted. All products are registered with the codes HS $50-$ HS 62. The real export value is generated from the calculation of the export value divided by the wholesale trade price index.

Exchange Rate ${ }_{i t}$ is the exchange rate of rupiah against the country "i" and " $t$ " time. Rupiah exchange rate in this research will use the exchange rate between Indonesia and five export destination countries. Then, Price ${ }_{i t}$ is the real price of Indonesian textile products to the country " $\mathrm{i}$ " and " $\mathrm{t}$ " time. Exports price state in USD/Kg that obtained through the calculation of the export value of textile products with the export value of textile exports. The third variable is dTariff ${ }_{i t}$ that the amount of change in import duty of textile products in the country " $i$ " and " $t$ " time. Finally, GDP per capita ${ }_{i t}$ is the level of Gross domestic product (PDB) per capita in the country " $i$ " and " $t$ " time.

Panel data analysis has several techniques, namely, Pooled Least Square (PLS) or Common Effect Model, Fixed Effect Model, and Random Effect Model. PLS is the most straightforward panel data model approach. This model only combines time-series data and cross-section. This model does not calculate the dimension of time and individuals, or it can say that the available data is the same in various periods. A fixed-effect (FE) model is a regression method that estimates panel data by adding dummy variables. While the random-effect model estimates by calculating the error of regression with the generalized least square (GLS). The random effect model is a variation of the generalized least square estimate.

As an effort to determine the method used between PLS and fixed effect, then carry out a redundant fixed effect. After that, is to determine the method between PLS or random effect. As an effort to determine the method that used, then a Lagrange Multiplier (LM) test is carried out to see which method better to use. The final test is the Hausman test.

\section{Result and Discussion}

Each export destination country has different factors in influencing the export of Indonesian textile products. This research uses textile products that have competitiveness by using the RCA method (Revealed Comparative Advantage) that first introduced by Balasa in 1965. Balassa assumed that a country's comparative advantage reflects through exports. Revealed Comparative Advantage (RCA) is one indicator that can show the comparative advantage of a commodity or a country's industrial competitiveness in the global market (Balassa, 1965). If RCA calculation results show RCA value higher than one, it means that a country has a comparative advantage above the world average. Therefore, these commodities have weak competitiveness (Kusuma \& Firdaus, 2015). 
In general, all the factors that analyzed significantly affect TPT exports. The estimation results in this panel data analysis were obtained based on TPT that have competitiveness in the world. Five products have competitiveness in the world based on the RCA method, namely products with the code HS 52, HS 54, HS 55, HS 61, and HS 62. The estimation carries out five destination countries such as the United States, China, Japan, South Korea, and Turkey.

Table 1. Panel Data Equation Result

\begin{tabular}{llcc}
\hline No & \multicolumn{1}{c}{ Variable } & Coefficient & Prob. \\
\hline 1 & Constanta & 2.450 & 0.000 \\
2 & GDP per capita & 0.379 & 0.000 \\
3 & Price & 1.021 & 0.000 \\
$4 \quad$ IDR Exchange Rate & 0.101 & 0.000 \\
5 & Tariff & -1.801 & 0.001 \\
\hline R-squared & \multicolumn{2}{c}{0.936} \\
Adjusted R-squared & \multicolumn{2}{c}{0.933} \\
F-statistic & \multicolumn{2}{c}{277.033} \\
Prob. (F-statistic) & \multicolumn{2}{c}{0.000} \\
Durbin-Watson stat & \multicolumn{2}{c}{0.435} \\
\hline
\end{tabular}

The model that is using in this research is the random effect model. The factors that influence the flow of TPT trade show an Adjusted R-square value of 0.933 (93.3\%). The existence of the $\mathrm{R}$-square value illustrates that 93.3 percent of the diversity that occurs in TPT exports to the five export destination countries can explain by factors or variables that exist inside the model. Then only 6.4 percent is explained by other factors outside the model. Table 1 shows that GDP per capita will have a positive impact on TPT exports. The larger GDP per capita in importing countries creates a higher demand for imports (Eve \& Au, 2006). The positive effect of GDP per capita on the volume of bilateral trade also occurs in Pakistan (Khan et al., 2013). Guisan \& Cancelo (2002) also found that the GDP level variable as a variable that represents the supply side has a positive effect on exports.

The price is the value of an item that can be measured by the value of the money spent by a buyer to get goods or services. Based on what has explained previously that the price of a product can affect the offer. An offer is the number of goods offered by producers where producers can provide goods and services to consumers (Mankiw, 2007). According to Stiglitz (1993), if the value of an item is high, then the producer has an incentive to increase its production. Based on the estimation results in Table 1 shows that the price of the TPT has a positive impact on the value of exports.

Changes in exchange rates can change the relative price of a product to be more expensive or cheaper. This condition makes the exchange rate one of the tools to increase exports. Using a floating exchange rate system (depreciation or appreciation), the value of a currency will affect exports. Based on the estimation results, it found that there was a positive 
impact between the exchange rate and exports. A positive effect on the rupiah exchange rate also occurred in rubber and areca commodity exports (Putra et al., 2017)

This influence occurs because when the value of the currency weakens, the price of foreign goods is relatively lower compared with domestic goods, which encourages exports. Other research also found the same thing that depreciation in the exchange rate will increase the competitiveness of export goods and will encourage increasing the value of exports (Ekananda, 2004). In general, the rupiah exchange rate against currencies in five export destination countries showed a weakening trend throughout 2001-2017. The downward trend in the exchange rate of the Rupiah against the five export destination countries is directly proportional to the increase in the export value of textile products. Import tariffs in export destination countries will hold up Indonesian TPT exports. Therefore, the estimation results show that the changes in import tariffs have a negative impact on textile exports. The decline in exports occurred because of an increase in costs that must be incurred to import textile products into the country. Based on this, if a country lowers its import tariffs, it will become an opportunity for Indonesia to increase exports of textile products.

This condition is the same as what happened in Brazil. The Brazilian government is considering to reduce import tariffs to cut the production costs-the tariff reduction targeted for imported raw materials (Trevisani, 2015). The reduction in import tariffs on rubber products in the amount of 50\%-75\% will have an impact on falling rubber export prices from several export countries to Australia. Based on this, exports of rubber products to Australia increased (Zainuddin et al., 2019). Mira \& Saptanto (2017) found that a reduction in import tariffs will increase exports of marine and fishery products. The tariff reduction is following the agreement of the ASEAN Economic Community.

China is one of the countries that made trade agreements. China has signed a trade agreement with an ASEAN country. China does not provide import tariffs originating from ASEAN countries for textile products except with the code HS 62 (Indonesian Ministry of Trade, 2015). Free trade agreements also made between the United States and South Korea. The agreement is called KORUS. The existence of the free trade agreement makes the import value of US apparel products from South Korea almost three times the export value of the same products from the United States to South Korea. (Hwang \& Norton, 2012)

Indonesia has made cooperation with several countries, including Japan and South Korea. Trade cooperation between Indonesia and Japan is called the Indonesia-Japan Economic Partnership Agreement (IJ-EPA). Then, the trade cooperation between Indonesia and South Korea called Indonesia - Korea Comprehensive Economic Partnership Agreement (IK-CEPA). However, build upon the Representative of United States Trade that the United States only has free trade agreements only with 20 countries. Among the 20 countries, Indonesia not registers. Similar to the United States, there is no free trade agreement between Indonesia and Turkey found. 
Faizal Irvansyah. The Determinants of Indonesian Textile's and Clothing

Table 2. Estimated Result for Equation of Export to the United States

\begin{tabular}{clcc}
\hline No & Variable & Coefficient & Prob. \\
\hline $\mathbf{1}$ & Constanta & 11.779 & 0.0003 \\
$\mathbf{2}$ & GDP per capita & 0.800 & 0.0281 \\
$\mathbf{3}$ & Price & 0.004 & 0.8326 \\
$\mathbf{4}$ & IDR Exchange Rate & -0.230 & 0.4141 \\
$\mathbf{5}$ & Tariff & -3.433 & 0.0084 \\
\hline R-squared & & 0.433 & \\
Adjusted R-squared & & 0.227 & \\
Durbin-Watson stat & \multicolumn{3}{c}{1.560} \\
\hline
\end{tabular}

Basically each country has different factors to influence the export of Indonesian TPT products. The biggest export destination country is the United States of America. Based on the result of RCA analyst, the product with the code HS 62 (articles of apparel and clothing accessories, not knitted or not crocheted) is the highest level of competitiveness in the United States of America. Table 2 shows that the factors that had an impact are GDP per capita and import tariffs. If the GDP per capita of the United States of America increases by $1 \%$, the TPT exports increase by $0.80 \%$. Besides, the second factor that affecting TPT exports is import tariffs. If the United States import tariffs decrease by $1 \%$, the TPT export will increase in the amount of $3.43 \%$.

Table 3. Estimated Result for Equation of Export to Japan

\begin{tabular}{clcc}
\hline No & Variable & Coefficient & Prob. \\
\hline $\mathbf{1}$ & Constanta & 6.570 & 0.099 \\
$\mathbf{2}$ & GDP per capita & -0.377 & 0.335 \\
$\mathbf{3}$ & Price & 1.376 & 0.001 \\
$\mathbf{4}$ & IDR Exchange Rate & 0.614 & 0.014 \\
$\mathbf{5}$ & Tariff & -0.290 & 0.001 \\
\hline R-squared & \multicolumn{2}{c}{0.893} \\
Adjusted R-squared & \multicolumn{2}{c}{0.850} \\
Durbin-Watson stat & \multicolumn{2}{c}{1.676} \\
\hline
\end{tabular}

The second-largest export destination country is Japan. The estimation result for Japan is obtained based on the product with the highest level of competitiveness, namely the product with the codes HS 55. Table 3 shows that the significant factors affecting Indonesian textile exports are textile products prices, exchange rates, and Japan import tariffs. If the price of textile products in Japan increases by $1 \%$, then Indonesian textile exports will increase by $1.37 \%$. Then, if the Indonesian exchange rate against the Japanese currency weakens by $1 \%$, Indonesia's exports will increase by $0.61 \%$. Finally, if Japan decreases import tariffs by $1 \%$, then Indonesia's textile exports will increase by $0.29 \%$. 
Table 4. Estimated Result for Equation of Export to China

\begin{tabular}{clcc}
\hline No & Variable & Coefficient & Prob. \\
\hline 1 & Constanta & -10.425 & 0.020 \\
2 & GDP per capita & 1.093 & 0.015 \\
3 & Price & 0.147 & 0,649 \\
4 & IDR Exchange Rate & 1.089 & 0.242 \\
5 & Tariff & -2.271 & 0.020 \\
\hline R-squared & \multicolumn{2}{c}{0.949} \\
Adjusted R-squared & \multicolumn{2}{c}{0.924} \\
Durbin-Watson stat & \multicolumn{2}{c}{2.395} \\
\hline
\end{tabular}

The third-largest export destination country is China. This estimation result based on the highest level of competitiveness is the textile product with the code HS 52. The factors that significantly influence Indonesian textile exports are GDP per capita and import tariffs of China. Table 4 shows that if the GDP per capita in China increased by $1 \%$, then Indonesia's textile exports will increase by $1.09 \%$. If the import tariff stipulates by the Chinese government drops by $1 \%$, then Indonesia's textile exports will increase by $2.27 \%$.

Furthermore, South Korea also has the same factors as Japan. Although the factors that influence textile exports are the same as Japan, the influence of South Korean currency on Rupiah has a negative effect. This condition is different from other export destination countries. Based on research by Ekananda (2004), stated that there is an uncertain effect of the exchange rate on the nominal export of commodities. The uncertain influence can cause by several factors, including the grouping of data differing according to import content, different by destination countries, and different by industry group. Even for Pakistan, the exchange rate in Pakistan does not affect exports (Ahmad et al., 2017).

Table 5. Estimated Result for Equation of Export to South Korea

\begin{tabular}{clcc}
\hline No & Variable & Coefficient & Prob. \\
\hline $\mathbf{1}$ & Constanta & 5.587 & 0.001 \\
$\mathbf{2}$ & GDP per capita & 0.162 & 0.268 \\
$\mathbf{3}$ & Price & 0.873 & 0.000 \\
$\mathbf{4}$ & IDR Exchange Rate & -0.392 & 0.003 \\
$\mathbf{5}$ & Tariff & -0.204 & 0.004 \\
\hline R-squared & \multicolumn{2}{c}{0.967} \\
Adjusted R-squared & \multicolumn{2}{c}{0.948} \\
Durbin-Watson stat & \multicolumn{2}{c}{1.397} \\
\hline
\end{tabular}

Table 5 shows that the factors that significantly affect Indonesia's TPT exports to South Korea are textile prices, exchange rates, and import tariffs of South Korea. If the price of TPT products in South Korea increases by $1 \%$, Indonesian TPT exports will increase by $0.87 \%$. If the Indonesian exchange rate against the South Korean currency weakens by $1 \%$, Indonesia's 
TPT exports will decrease by $0.39 \%$. Finally, if the countries of South Korea decrease import tariffs by $1 \%$, then Indonesia's textile exports will increase by $0.20 \%$. The estimation results are obtained based on products with the code HS 55.

The fifth-largest export destination country is Turkey. Indonesian's textile products that have the highest level of competitiveness based on RCA is HS code 55. The factors affecting Indonesia's TPT exports to Turkey are GDP per capita and import tariffs. If Turkey's GDP per capita increases by $1 \%$, Indonesia's TPT exports will increase by $1.37 \%$. If there is a reduction in import tariffs stipulate by the Turkish government by $1 \%$, Indonesia's TPT exports will increase by 0.79 .

Table 6. Estimated Result for Equation of Export to Turkey

\begin{tabular}{clcc}
\hline No & Variable & Coefficient & Prob. \\
\hline $\mathbf{1}$ & Constanta & 7.610 & 0.067 \\
$\mathbf{2}$ & GDP per capita & 1.373 & 0.000 \\
$\mathbf{3}$ & Price & 0.443 & 0.176 \\
$\mathbf{4}$ & IDR Exchange Rate & 0.256 & 0.439 \\
$\mathbf{5}$ & Tariff & -0.791 & 0.006 \\
\hline R-squared & \multicolumn{2}{c}{0.950} \\
Adjusted R-squared & \multicolumn{2}{c}{0.925} \\
Durbin-Watson stat & \multicolumn{2}{c}{1.676} \\
\hline
\end{tabular}

The result of this study can help increase TPT export. This research suggests that the Indonesian government can maintain the movement of the Rupiah against foreign currencies and also expected to continue to establish trade cooperation with other countries. This condition is because among the five countries analyzed, Indonesia only has free trade agreements with China, Japan, and South Korea. Then, The Indonesian government suggests increasing the role of the ITPC (Indonesia Trade Promotion Center). Besides that, the government should also expand ITPC locations in promoting Indonesian textile products. The existence of ITPC can help connect the trade relations between Indonesia and Indonesian export destinations. The existence of ITPC will eliminate non-tariff barriers because the existence of ITPC institutions will provide information related to market conditions in the country. So that Indonesian TPT exports can continue to increase.

\section{Conclusion}

Using a random effect analysis panel data shows that GDP per capita, the exchange rate of the Rupiah against export destination countries, the price of Indonesian textile products, and changes in import tariffs imposed in export destination countries significantly affect the trade flow (exports) of Indonesian textile products. The results based on Indonesian textile products that have competitiveness in the world. The results also showed the R-square value of $0.9880(98.8 \%)$ and adjusted R-square of 0.9866 (98.6\%). Factors of GDP per capita, rupiah exchange rate, and the price of Indonesian textile products have a positive effect on 
exports. Meanwhile, the import tariffs imposed on destination countries have a negative effect on Indonesian exports.

Each country has different factors to influence the export of Indonesian TPT products.. The results show that each country has different factors. The time series analysis carries out using Indonesian TPT product data that has the highest level of competitiveness in each destination country. Factors that influence significantly for the United States, China, and Turkey are GDP per capita and import tariffs. Then for Japan and South Korea, including textile price, exchange rate, and tariff factors. In general, the rupiah exchange rate has a positive effect on Indonesian textile exports. However, there was a negative influence in South Korea.

\section{References}

Ahmad, K., Qasim, M., \& Chani, M. I. (2017). Impact of Exchange rate on Exports in Case of Pakistan. Bulletin of Business and Economics, 6(2), 98-102.

Asmara, A., Yeti L. P., Sri M., \& Tanti N. (2016). The Alternative Strategy For Strengthening Indonesian Textile and Clothing Industry Structure. Jurnal Bisnis \& Manajemen, 17(1), 33-47.

Balassa, B. (1965). Trade Liberalisation and "Revealed" Comparative Advantage. Manchaster School. 33(2), 327-344. https://doi.org/10.1111/j.14679-957.1965.tb00050.x

Baskol, A. O. (2018). International Competitiveness in Turkish Textile and Clothing Sector. Journal of Management Economics and Business, 14(3), 643-658.

Chamroel, D. (2003). Ideas Regarding TEXTILE'S Industry and Trade Development. Jakarta: API \& Cidesindo.

Ekananda, M. (2004). Analisa Pengaruh Volatilitas Nilai Tukar Pada Ekspor Komoditi Manufaktur Di Indonesia (Analysis of the Effect of Exchange Rate Volatility on Exports of Manufacturing Commodities in Indonesia). Buletin Ekonomi Moneter dan Perbankan, 7(2), 197-235

Eve, M. H. C., \& Au, K. F. (2006). Determinants of China’s Textile Exports: An Analysis By Gravity Model. Journal of The Textile Institute, 98(5), 463-469

Guisan, M., \& Cancelo, M. (2002). Econometric Models of Foreign Trade in OECD Countries. Econometrics and International Development, 2(2), 65-81.

Harjanto, E., \& Purwanto, E. H. (2010). Konversi Standar Nasional Indonesia [SNI] ke Harmonized System [HS] (Conversion of Indonesian National Standard [SNI] to Harmonized System [HS]). Jurnal Riset Industri, 4(2), 41-56.

Hatab, A. A. (2017). Made in China: The Displacement Effect of China on Egyptian Textile Export. Journal of Agribusiness in Developing And Emerging Economies, 7(2), 99-114.

Hendria, M. (2017). Strategi Pengembangan dan Peningkatan Daya Saing Industri Pakaian Jadi Indonesia (Strategy for Developing and Increasing the Competitiveness of the Indonesian Apparel Industry). (Unpublished Thesis). Bogor: IPB University.

Hwang, E. J., \& Norton, M. J. (2012). United states-korea free trade agreement and effects on the U.S. and korean textile and apparel industries. The Business \& Management Review, 3(1), 129-137. 
Faizal Irvansyah. The Determinants of Indonesian Textile's and Clothing

Indonesian Ministry of Trade. (2015). Analysis of Import Policies In Export Destination Countries. Jakarta: Secretariat of the Directorate General of Foreign Trade.

Kathuria, L. M. (2013). Analyzing Competitiveness of Clothing Export Sector of India and Bangladesh. Competitiveness Review, 23(2), 131-157.

Khan, S., ul Haq, I., \& Khan, D. (2013). An Empirical Analysis of Pakistan's Bilateral Trade: A Gravity Model Approach. The Romanian Economic Journal, 16(48), 103-120.

Kuncoro, M. (2013). Indonesia's Textile and Its Products Industry: Recent Development and Chalanges. International Journal of Business and Economic Development, 4(2), 60-74.

Kusuma, R. L., \& Firdaus, M. (2015). Daya Saing dan Faktor yang Mempengaruhi Volume Ekspor Sayuran Indonesia Terhadap Negara Tujuan Utama (Competitiveness and factors affecting Indonesia's Vegetable Export Volume Against Major Destination Countries). Jurnal Manajemen dan Agribisnis, 12(3), 226-236.

Latif, R., \& Javid, A. Y. (2016). The Determinants of Pakistan Exports of Textile and Integrated Demand and Supply Approach. The Pakistan Development Review, 55(3), 191-210.

Mankiw, N. G. (2007). Principles of Economic (4th Edition). USA: Thompson Higher University.

Mira., \& Saptanto, S. (2017). Pengaruh Kebijakan Perubahan Tarif Impor Terhadap Sektor Kelautan dan Perikanan (The Effect of Import Tariff Policy on The Maritime and Fisheries Sector). Jurnal Kebijakan Sosial Ekonomi Kelautan dan Perikanan, 7(1), 13-25

Putra, M. A., Emilia., \& Chandra, M. (2018). Pengaruh Kurs dan Harga Ekspor Komoditas Unggulan Provinsi Jambi (The Effect of Exchange Rate and Jambi Province Commodity Export Commodity Prices). e-Journal Perdagangan, Industri, dan Moneter, 6(1), 45-61.

Schwab, K. (2017). The Global Competitiveness Report 2017-2018. Geneva: World Economic Forum.

Stiglitz, J. (1993). Principles of Macroeconomic. New York: W.W. Norton and Company, Inc.

Trevisani, P. (2015). Brazil Studies Cutting Import Tariffs. Wall Street Journal, 1-3. Retrieved from: https://www.wsj.com/articles/SB10001424127887324110404578628490871 293104

Wahyuni,S., \& Boeditomo, P.T. (2015). Does Quality of Work Life Influence Competitiveness? A Comparison Between Indonesia and Vietnam. Global Business and Managemenent Research: An International Journal, 7(1), 32-59.

Zainuddin., Sinaga, B. M., Hartoyo, S., \& Erwidodo. (2019). Assessing Market Power, Impact of Import Tariff Reductions and Weakening Demand for Rubber Products (HS Code 4011) in the Australian Market. International Journal of Economic and Financial Issues, 9(2), 59-72

Zyl, G. V., \& Matswalela, K. (2016). A Comparative Analysis of The Level of Competitiveness of The South African Clothing and Textile Industry. Journal of Economic and Financial Sciences, 9(2), 370-391. 